\title{
Integration of the EAEU Countries: Qualitative Changes
}

\author{
Natalya Yu. Sopilko 1[ORCID 0000-0002-1309-6553], \\ Valeriy M. Tumin ${ }^{2 *[O R C I D ~ 0000-0003-4651-0359], ~}$ \\ Irina Yu. Eremina 1[ORCID 0000-0003-1444-2259], \\ Elena V. Zenkina 3[ORCID 0000-0003-2192-4715], \\ Olga P. Ivanova 4[ORCID 0000-0002-9563-4166]
}

\author{
${ }^{I}$ National University of Oil and Gas “Gubkin University”, Moscow, Russia \\ ${ }^{2}$ Moscow Polytechnic University, Moscow, Russia \\ ${ }^{3}$ Russian State University for the Humanities, Moscow, Russia \\ ${ }^{4}$ Yaroslav-the-Wise Novgorod State University, Veliky Novgorod, Russia \\ vm@tumin.net
}

\begin{abstract}
The paper presents an analysis of various modern approaches to assessing the integration effects of countries in international practice regarding the quality of their development. The main goal of the study is to substantiate the economic feasibility of further development of the integration of the EAEU member states, within the framework of which the task was set to form a specific approach to assessing the quality effects of the economic integration of the EAEU countries from the standpoint of ongoing reforms, opportunities to improve the welfare of the population, the quality of life of the population, etc. The authors have carried out a comparative analysis of various quality parameters in relation to the transformational reforms carried out in the EAEU region in comparison with some post-Soviet countries, have analyzed the main characteristics of the Doing Business data, the dynamics of the Human Development Index, global competitiveness, quality of life, the Gini index, etc. The obtained results substantiate the fact that integration ties have a positive impact on the socio-economic development of the countries. Based on this analysis, some problems in the activities of the EAEU states regarding the development of integration processes have been highlighted, and they indicate that the Eurasian countries need the development of quality institutions; also, the shortcomings in the development of industry and the need to form value-added chains have been indicated. The conclusion has been made about the weakness of the institutional basis of the EAEU, and the possibilities for the development of integration processes for reforms in various areas of the economy. It is also shown that a quality assessment of indicators should be carried out over a longer period of reforms than the EAEU exists and can be supported by quantity methods, for example, predictive dynamics of the main macroeconomic indicators of the countries or other methods of economic and mathematical modeling.
\end{abstract}

Keywords: regional economic integration, integration effects, the EAEU states, quality assessment of integration

\section{INTRODUCTION}

Regional economic integration is currently an integral part of the modern world economy. An extensive theoretical and practical research base in the field of integration processes has been accumulated. Both in the domestic scientific and expert community and the foreign one, there is a stable idea of how to analyze the processes of regional integration. However, at the same time, there is still no universal methodology for their assessment in world practice.

The studies of this area, despite the depth, diversity, and multiplicity, do not allow to unambiguously draw general conclusions about the 
nature of the impact of integration on the economy of the participants in this process. World economic trends indicating a high degree of turbulence and uncertainty have influenced the development trajectory of many regional integration associations, including the Eurasian Economic Union (EAEU). The EAEU is a recently formed, dynamically developing regional grouping created with the participation of five post-Soviet countries (Russia, Belarus, Kazakhstan, Armenia, and Kyrgyzstan).

At the level of the EAEU, the idea of the Greater Eurasian Partnership has been updated [1] According to the experts, the formation of the Greater Eurasian Partnership should become for the EAEU a clearly verified and dynamically implemented strategy requiring an assessment of the prospects for the development of the grouping itself and the vectors of its development. Therefore, the study of approaches to assessing integration effects is relevant. It is important to assess the role, significance, economic results, quality, and development prospects of the formed region, taking into account its features in the current realities of world economic processes.

\section{MATERIALS AND METHODS}

The main purpose of the study is to assess the current quality effects of the economic integration of the EAEU countries in the context of modern global trends, to analyze quality changes in the conditions of integration processes of countries over the period of increasing well-being of the region's population, the level of quality of life in the participating countries, etc. The study is based on the hypothesis that the integration processes in the EAEU space the development of the Union, have contributed to the stabilization of transformation processes, the preservation of old, and the development of new economic ties between the EAEU member states, and the obtaining of integration effects.

To conduct such a study, general scientific methods of analysis, logical generalization, and comparison of the countries of the EAEU region with some countries of the selected reference group, namely the countries of the post-Soviet space, have been used, taking into account the characteristics and various factors of the external and internal environment of the region.

Methodological recommendations and statistical data, analytical materials of the United Nations (UN), the World Bank (WB), the World Trade Organization (WTO), the Organization for
Economic Co-operation and Development (OECD), as well as data presented in reports of the Eurasian Economic Commission (EEC) have been used as an information base.

Theoretical works on the problems of the effects of regional economic integration are divided into traditional theories of economic integration based on static analysis, mainly explaining trade integration effects (J. Viner, B. Balassa, J. Meade, etc.), and new theories that have arisen in the context of the evolution of economic landscape and operate with a dynamic analysis of economic integration (H. Sadek, M. Emiris, G. Debreu, etc.). Such methods are based on the study of dynamic trading indicators, factors of capital and labor, theoretical concepts of the Pareto theory regarding value-added, etc. [2]. They have formed an interdisciplinary approach in the scientific community, which makes it possible to assess promising areas and form a picture of the results of economic integration, which could not be done using static approaches.

These methods include the calculation of gross domestic product (GDP), which makes it possible to assess the main benefits of the participating countries from the integration [3]. It is noted that the larger the economy participates in the integration process, the lower the growth of the GDP indicator takes place, and productivity also grows at a slower pace, in contrast to smaller players. This conclusion is not new, however, it has been with the development of these directions in science that it has received a mathematical proof and has been confirmed.

The dynamic assessment method has become quite widespread, for example, it was used to calculate forecasts of the rates of domestic savings of the countries-members of integration groupings. It has been substantiated that all countries of this process are striving for a single rate [4], etc.

When integration processes began to actively expand in the European space and other continents, it turned out that a quantitative assessment of the effects of these processes could not be limited to the growth of mutual trade. In this regard, it became necessary to expand the methodology of this direction. Thus, in the early 2000s, the European Central Bank proposed its methodology for assessing integration effects, based on both quantitative analysis and qualitative comparisons [5].

Along with the European Bank, such methods were proposed by other international organizations, 
namely, the OECD which developed a comprehensive system of economic criteria that precisely reflected the development of intra-regional trade, which significantly distinguished this approach from the method of the European Central Bank [6].

A very popular and advanced, according to the experts [7], and the most relevant for the current state of the world economy comprehensive methodology is the one formed by the Asian Development Bank in the early 2010s.

Like the previous methods, it considers the integration process as a process of formation, subsequent strengthening, and expansion of economic ties between the markets of countries participating in the integration. Evaluation of the effects takes place in the context of the development of mutual trade.

In addition to the described methods, such wellknown, well-established methods based on the calculation of the Herfindahl-Hirschman index, structural shift index, concentration index, the Gini index, and many others are widely used at present [8].

Generally accepted estimates based on gravity models which allow making calculations regarding forecasts of trade volumes in relation to the level of GDP of countries, inversely proportional to the distance between these states, are also popular [9].

However, it should be noted that all these methods require a wide amount of data and a long study period for a more accurate assessment of integration effects. Although, in the European Union (EU), for example, the immediate effects of market opening were observed, even despite a short period, and it was noted that they were more dynamic than the ongoing processes in the Eurasian region. This is because, unlike the EAEU, where inter-industry cooperation is present in the majority, competing industries have integrated into the EU [10], which is obvious, since intra-industry cooperation generates the greatest competition. And the EAEU member states, for a long period, formed a common economic complex within the USSR.

In this regard, for a more accurate analysis of integration processes in the EAEU, we have been using comparative analysis approaches for various parameters, to assess qualitative changes in the EAEU countries by the quality of transformational reforms carried out with the use of the Ease of Doing Business Index of the World Bank, the Human Development Index, etc.

\section{RESULTS}

Initially, the indicators of the dynamics of changes in some macroeconomic parameters of the EAEU states and the countries of the selected reference group (7 post-Soviet countries: Azerbaijan, Georgia, Ukraine, Moldova, Tajikistan, Turkmenistan, and Uzbekistan) have been analyzed. The general picture of the dispersion across the EAEU member states and the countries of the selected reference group for the period 2015-2020 is illustrated below in Figures 1, 2.

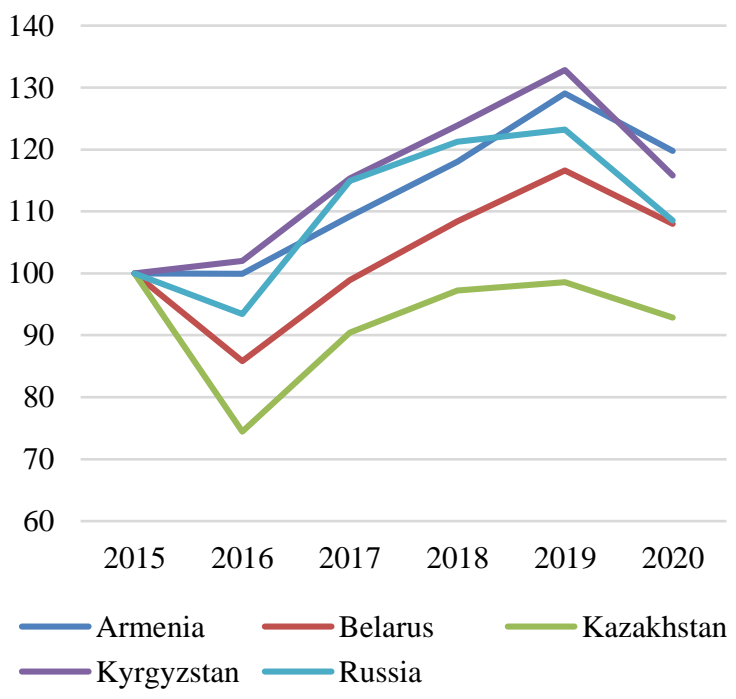

Figure 1. Dynamics of GDP growth rates of the EAEU countries, constant prices in $2011, \%$ by 2015 Source: Compiled by the authors according to [11]

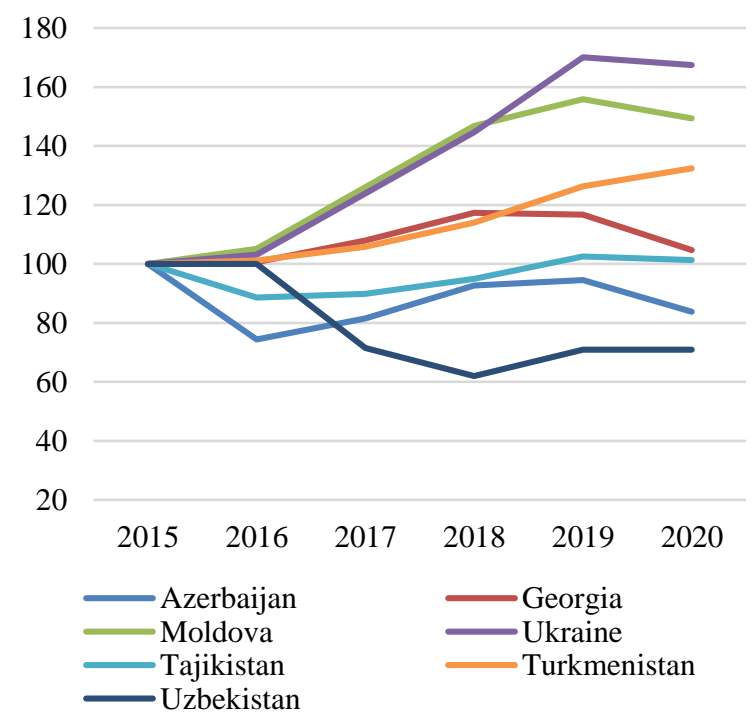

Figure 2. Dynamics of GDP growth rates of the countries of the reference group, constant prices in $2011, \%$ by 2015

Source: Compiled by the authors according to [11] 
These dynamics illustrate that, in general, the level of GDP growth of the EAEU states and the countries of the comparison group show a similar vector. At the same time, it can be noted that the dynamics of the GDP of the EAEU countries are more stable and do not show such changes and fluctuations as in other countries. In all countries, there was a drop in GDP in 2016, however, the EAEU countries had similar growth dynamics after the drop, unlike the countries of the reference group. Perhaps the reason for such turbulence was the destruction of previously existing close economic ties, which led to various inter-company effects and was lost with the collapse of the USSR. And within the framework of the EAEU region, such ties have been partially preserved and further developed, which is why there is a more stable picture of the growth of macroeconomic indicators in general.
Also, all countries showed a decline in GDP in 2020, which is explained by the significant impact of the COVID-19 pandemic that has engulfed the world. However, in general, the stability of the economies of the EAEU countries to external shocks is noted, in contrast to the countries of the comparison group.

According to Table 1, we observe a picture of the initial and final state of the demographic parameters of the EAEU states and the level of development over twenty years of transformational reforms in the EAEU countries. It can be observed that, since 2010, there is progress in both major macroeconomic parameters. Qualitative shifts are shown, which allow us to conclude about the positive changes that in the case of the EAEU member states, it is the integration that has allowed them, namely, changes in the labor market (growth of migration processes and population in the countries of the region).

Table 1. GDP per capita according to PPP (2011 prices), population

\begin{tabular}{|l|c|c|c|c|c|c|}
\hline \multirow{2}{*}{ Country } & \multicolumn{3}{|c|}{ GDP per capita, thousand dollars } & \multicolumn{3}{c|}{ Population, million people } \\
\cline { 2 - 7 } & $\mathbf{2 0 0 0}$ & $\mathbf{2 0 1 0}$ & $\mathbf{2 0 2 0}$ & $\mathbf{2 0 0 0}$ & $\mathbf{2 0 1 0}$ & $\mathbf{2 0 2 0}$ \\
\hline Armenia & 3.04 & 3.51 & 13.3 & 3.08 & 2.97 & 3.04 \\
\hline Belarus & 7.6 & 15.0 & 20.2 & 9.99 & 9.51 & 9.42 \\
\hline Kazakhstan & 10.0 & 18.8 & 26.6 & 14.87 & 16.20 & 19.78 \\
\hline Kyrgyzstan & 2.1 & 2.8 & 5.04 & 4.92 & 5.42 & 6.3 \\
\hline Russia & 14.1 & 22.1 & 27.9 & 146.4 & 143.13 & 147.7 \\
\hline
\end{tabular}

Source: Compiled by the authors based on [12]

The dynamics of investment growth in fixed assets of the EAEU states (Figure 3) also demonstrated growth, with the exception of 2020 against the background of the global crisis.

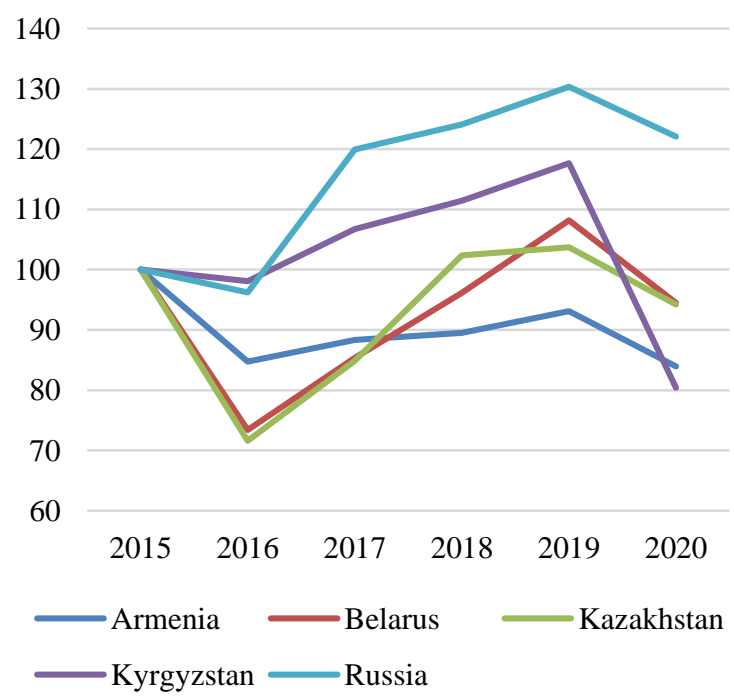

Figure 3. Dynamics of growth rates of investments in fixed assets of the EAEU countries, \% by 015 Source: Compiled from [13]
In the study, to assess the quality of integration in the EAEU region, comparative parameters were made with respect to the quality of transformational reforms. For this, the well-known methodology of the EBRD was used, based on a comparison according to various indicators of the development of states [14] (Table 2).

They are defined as complex metrics based on multiple characteristics, large amounts of data, and expert assessment.

They are given within the framework of the method of scales - from 1 to 10 (the more, the better).

The data obtained, presented in the table, as well as the general picture for the EAEU states and the comparison countries, is the same as before - most of the indicators of the EAEU region are higher than those of other countries of the reference group. It also shows that integration allows countries to reap additional benefits.

We observe a rather optimistic picture when analyzing the survey data of Doing Business (Table 3) $[15]$. 
Table 2. Comparative assessment of the level of indicators of the transition period in 2018-2019: general indicators

\begin{tabular}{|c|c|c|c|c|c|c|c|c|c|c|c|c|}
\hline \multirow{2}{*}{$\begin{array}{c}\text { Index } \\
\text { Country }\end{array}$} & \multicolumn{2}{|c|}{ Competitive } & \multicolumn{2}{|c|}{ Well-governed } & \multicolumn{2}{|c|}{ Green } & \multicolumn{2}{|c|}{ Inclusive } & \multicolumn{2}{|c|}{ Resilient } & \multicolumn{2}{|c|}{ Integrated } \\
\hline & 2019 & 2018 & 2019 & 2018 & 2019 & 2018 & 2019 & 2018 & 2019 & 2018 & 2019 & 2018 \\
\hline \multicolumn{13}{|c|}{ Reference group countries } \\
\hline Azerbaijan & 3.73 & 3.6 & 5.75 & 5.42 & 5.24 & 4.96 & 4.96 & 4.81 & 3.98 & 3.88 & 6.04 & 5.85 \\
\hline Georgia & 4.54 & 4.53 & 6.32 & 6.44 & 5.53 & 5.25 & 5.6 & 5.42 & 6.01 & 5.84 & 6.4 & 6.25 \\
\hline Moldova & 4.29 & 4.28 & 4.62 & 4.51 & 4.78 & 4.52 & 6.01 & 5.69 & 5.47 & 5.26 & 5.39 & 5.45 \\
\hline Ukraine & 4.67 & 4.64 & 4.55 & 4.44 & 5.8 & 5.8 & 6.01 & 5.99 & 5.6 & 4.88 & 4.92 & 4.88 \\
\hline Tajikistan & 3.00 & 3.00 & 3.73 & 3.76 & 4.94 & 4.69 & 5.15 & 4.7 & 3.49 & 3.26 & 3.98 & 3.85 \\
\hline Turkmenistan & 2.79 & 2.8 & 2.25 & 2.37 & 3.8 & 3.8 & 5.56 & 5.27 & 3.17 & 3.36 & 4.39 & 4.26 \\
\hline Uzbekistan & 3.28 & 3.32 & 3.41 & 3.59 & 4.43 & 4.05 & 5.65 & 5.69 & 3.89 & 3.89 & 3.58 & 3.5 \\
\hline \multicolumn{13}{|c|}{ EAEU countries } \\
\hline Armenia & 4.51 & 4.46 & 5.81 & 5.72 & 5.76 & 5.47 & 5.95 & 5.61 & 6.08 & 6.21 & 5.98 & 5.78 \\
\hline Belarus & 4.69 & 4.5 & 5.08 & 4.94 & 6.26 & 6.26 & 7.03 & 6.91 & 3.64 & 3.6 & 5.62 & 5.49 \\
\hline Kazakhstan & 5.07 & 4.95 & 5.58 & 5.72 & 5.13 & 4.86 & 6.06 & 6.06 & 6.02 & 6.01 & 5.25 & 5.21 \\
\hline Kyrgyzstan & 3.66 & 3.66 & 4.06 & 4.09 & 4.56 & 4.55 & 4.94 & 4.76 & 5.05 & 5.1 & 5.12 & 4.92 \\
\hline Russia & 5.21 & 5.12 & 5.83 & 5.77 & 5.08 & 5.07 & 7.16 & 7.13 & 6.3 & 6.24 & 5.49 & 5.38 \\
\hline
\end{tabular}

Source: Compiled by the authors based on [14]

Table 3. Dynamics of indicators of the Doing Business rating

\begin{tabular}{|l|c|c|c|}
\hline Country & $\mathbf{2 0 1 5}$ & $\mathbf{2 0 2 0}$ & Change (+/-) \\
\hline Armenia & 49 & 47 & +2 \\
\hline Belarus & 57 & 49 & +8 \\
\hline Kazakhstan & 77 & 25 & +52 \\
\hline Kyrgyzstan & 102 & 80 & +22 \\
\hline Russia & 62 & 28 & +34 \\
\hline Azerbaijan & 80 & 34 & +46 \\
\hline Georgia & 15 & 7 & +8 \\
\hline Moldova & 63 & 48 & +15 \\
\hline Uzbekistan & 141 & 69 & +72 \\
\hline Ukraine & 96 & 64 & +32 \\
\hline
\end{tabular}

Source: Compiled by the authors from [15]

According to the presented dynamics over the last five-year period of the EAEU activities, an increase in indicators can be noted in Russia and Kazakhstan (from $62^{\text {nd }}$ to $28^{\text {th }}$, from $77^{\text {th }}$ to $25^{\text {th }}$, respectively). Changes have also taken place in Belarus (from $57^{\text {th }}$ to $\left.49^{\text {th }}\right)$. Kyrgyzstan also improved its position, taking the $80^{\text {th }}$ position. Armenia practically remained at the same level, slightly increasing the rating $(+2)$ and taking $47^{\text {th }}$ place.

If we trace the positions of the countries of the reference group, it can be noted that only Georgia managed to significantly increase its rating, improving its business environment (in 2019, taking $7^{\text {th }}$ place), as well as Azerbaijan (from $80^{\text {th }}$ to $34^{\text {th }}$ place), ahead of Belarus and Armenia.

Assessment of a comprehensive Doing Business indicator is complex, including various items. And it is necessary to note that the EAEU states have made very significant shifts in such important areas as the establishment of enterprises, property registration, enforcement of contracts. These indicators reflect the basis of economic development, the state of its real sector. Only Kyrgyzstan is lagging, which is associated with the geopolitical situation in the country and internal conflicts. If these characteristics are at a low level, the effects of integration slow down, since the difficulty and barriers in doing business are significant obstacles to integration processes in general in the EAEU space. In this regard, it is required to pay special attention to the development of the real economy of the region, as a priority, which has already been described earlier.

Of course, on the whole, the picture is in favor of the countries that have integrated into the Eurasian Union, as evidenced by the high rating of the business environment. However, until now, the weak side is the rating covering the foreign trade parameter. Moreover, Belarus and Armenia have relatively good indicators. In Kazakhstan and Russia, it is only 102 and 99, respectively. Several problems impede the improvement of the foreign trade sphere (sanctions, raw materials orientation of exports, intersectoral orientation, many barriers, including non-tariff ones, etc.).

According to the indicators cited in the report of the World Economic Forum, the ranking of the Global Competitiveness Index shows an improvement in the positions of the EAEU countries from 2015 to 2019 (Table 4). 
Table 4. Dynamics of the indicator of the Global Competitiveness Index

\begin{tabular}{|l|c|c|c|}
\hline Country & 2015 & 2019 & Change (+/-) \\
\hline Armenia & 82 & 69 & +13 \\
\hline Kazakhstan & 42 & 55 & +13 \\
\hline Kyrgyzstan & 102 & 96 & +6 \\
\hline Russia & 45 & 43 & +2 \\
\hline Azerbaijan & 40 & 58 & -18 \\
\hline Georgia & 66 & 74 & -8 \\
\hline Moldova & 84 & 86 & -2 \\
\hline Ukraine & 79 & 85 & -6 \\
\hline Tajikistan & 80 & 104 & -24 \\
\hline
\end{tabular}

Source: Compiled by the authors based on [16]

It is also noted that the Eurasian region occupies high positions in the following sub-indices: market size $\left(11^{\text {th }}\right.$ place), ICT implementation $\left(27^{\text {th }}\right.$ place), innovation activity ( $41^{\text {st }}$ place), and the indicator of business development dynamics $\left(50^{\text {th }}\right.$ place) [16]. At the same time, it is noted that all the EAEU states have achieved significant success in the field of ICT, which, in the context of modern economic development, is undoubtedly a strong point.

An important indicator that reflects the level of development of countries is the Gini index (data from the World Bank), which shows the degree of income inequality. Its assessment for the EAEU region is presented in Table 5, where there is an obvious tendency for this indicator to decrease in the EAEU countries in comparison with the countries from the reference group.

Table 5. Dynamics of the Gini index (2015-2019)

\begin{tabular}{|l|c|c|c|}
\hline Country & 2015 & 2019 & Change $(+/-)$ \\
\hline Armenia & 32.4 & 29.9 & +2.5 \\
\hline Belarus & 25.6 & 25.3 & +0.3 \\
\hline Kazakhstan & 26.8 & 27.8 & -1.0 \\
\hline Kyrgyzstan & 29.0 & 29.7 & -0.9 \\
\hline Russia & 37.7 & 37.5 & +0.2 \\
\hline Azerbaijan & 26.6 & 28.6 & -2.0 \\
\hline Georgia & 36.5 & 40.5 & -4.0 \\
\hline Moldova & 27.0 & 33.7 & -6.7 \\
\hline Ukraine & 25.5 & 26.6 & -1.1 \\
\hline Tajikistan & 34.0 & 44.7 & -10.7 \\
\hline
\end{tabular}

Source: Compiled by the authors based on [17]

According to Table 5, Armenia, Russia, and Belarus improved their performance in 2019 compared to 2015 . The best indicator is shown by Belarus. High levels of inequality are found in Tajikistan and Georgia.
The EAEU countries, having faced certain shocks and crises that swept the world during their integration period, have been able to achieve a significant improvement in population growth rates, both natural and migration. Also, the relative resilience of the countries during the recession which was the case with the global oil price shock was noted. At the same time, the effects that the EAEU member countries received were uneven, which was especially noted in the cases of smaller economies - Armenia and Kyrgyzstan (for example, in terms of ruble transfers, etc.) [18].

Also, the qualitative state within the EAEU is characterized by the indicator of the Human Development Index (Table 6).

Table 6. Dynamics of the HDI indicator (20152019)

\begin{tabular}{|l|c|c|}
\hline Country & 2015 & 2019 \\
\hline Armenia & $0.733(85)$ & $0.776(81)$ \\
\hline Belarus & $0.798(50)$ & $0.823(53)$ \\
\hline Kazakhstan & $0.788(56)$ & $0.825(51)$ \\
\hline Kyrgyzstan & $0.655(120)$ & $0.697(120)$ \\
\hline Russia & $0.798(50)$ & $0.824(52)$ \\
\hline Azerbaijan & $0.751(78)$ & $0.756(88)$ \\
\hline Georgia & $0.754(76)$ & $0.812(61)$ \\
\hline Moldova & $0.693(107)$ & $0.750(90)$ \\
\hline Tajikistan & $0.624(129)$ & $0.668(125)$ \\
\hline Ukraine & $0.747(81)$ & $0.779(74)$ \\
\hline Uzbekistan & $0.675(114)$ & $0.720(106)$ \\
\hline
\end{tabular}

Source: Compiled by the authors based on [19]

As evidenced by the Human Development Index, the first severe shock of 2015-2016 in Russia did not lead to a significant decrease in this indicator. The next period, up to 2019, allowed all EAEU countries to raise the Index's rating. Among the leaders were Belarus, Russia, and Kazakhstan. In the countries of comparison, a different situation is observed: their positions were lower than those of the states of the EAEU region. Only Georgia demonstrated a high level, however, there was a decrease in population. Other countries - Uzbekistan, Tajikistan - have practically no improvements in this direction. Positions were lost in Azerbaijan due to dependence on oil prices.

Therefore, for all the presented characteristics of qualitative changes for the period 2015-2020, the EAEU states, due to the development of integration ties between the countries, look more positive than in the countries of the reference group. 


\section{DISCUSSION}

The current state of the world economy is characterized by another period of instability and turbulence, which, according to many experts, will continue for a fairly long period [20-22]. Volatility is observed in almost all macroeconomic indicators, as well as major price indicators. At the same time, in the context of the crisis caused by a large-scale coronavirus pandemic, lockdowns, restrictions, etc., there is a certain lack of coordination of actions on the continents of Europe and America, accompanied, in particular, by disintegration processes. Many states are reorienting their views on further formats of interaction and cooperation development. However, in such difficult conditions, it is noted that more coordinated actions of the EAEU states and, in general, between countries in the Eurasian space [20], made it possible to partially neutralize the consequences of the ongoing crises.

As well as other regional associations, the EAEU is currently making every effort (funds are allocated to support the population, to support business, etc.), to overcome external challenges and stabilize the economic situation. Already today, as noted at EEF2021, the level of GDP has grown compared to 2020 and has reached the pre-pandemic level.

Obstacles to development, of course, remain the multiple internal contradictions of the EAEU countries, which is associated with a certain persisting imbalance in uneven economies, heterogeneity of macroeconomic indicators, disagreements on many issues on which there is a discrepancy between national and supranational interests, countries of loss of sovereignty, etc. Thus, the integration of the EAEU states has many contradictions, which are currently being analyzed by specialists, while simultaneously the issues of the prospects and expediency of further integration and the vectors of its development are being solved. At the same time, such studies [20], showing structural changes in the course of integration, the growth of macroeconomic indicators, confirm the positive effects of such processes and their impact on the economy of states as a whole.

There is an increase in certain competitive advantages in terms of the overall global picture, namely, an increase in the positions of the EAEU countries in various rankings [21].

However, along with the positive aspects, the presence of inertia in the integration processes on the part of all the EUEC countries [22] is emphasized, due to a variety of factors that only increase the negative impact and impede development. Firstly, these are the problems of the institutional development of the EAEU region, the inefficiency of the institutional system as a whole. Secondly, a large gap in the economic level of states has a significant negative impact on the growth of economies and their competitiveness. Thirdly, the internal problem of the limited powers of the EEC, leading to inconsistencies in the management and control of the region. Fourth, the low image indicators of the EAEU grouping: insufficient recognition of the subject of the world market as well as distrust from society, business, etc. within the region.

However, despite such difficult conditions and risks and many contradictions, it is noted that the EAEU, despite its short duration, has a large number of achievements in various areas of socio-economic development and has taken place as a regional grouping.

\section{CONCLUSION}

In the course of the study, the authors substantiated that all the EAEU member states have received certain benefits from the development of integration processes. Based on the results of the assessment of various indicators in the region of the EAEU states, the positive effects of the influence of integration, certain qualitative shifts in the development of the institutional basis for doing business are evident, which are as follows:

- the presence of a certain stability of the economies of the EAEU countries in relation to various external shocks relative to other post-Soviet countries that are not participating in the integration processes;

- manifestation of the adaptability of the labor market in the context of economic imbalances for the EAEU member states;

- improving the parameters of the development of the institutional environment within the framework of internal liberalization, indicators of international assessments;

- growth trends in the dynamics of the main macroeconomic indicators.

During the analysis, against the background of positive trends, several problems existing in the EAEU region have been highlighted, among which: lack of quality institutions (institutions of private property have not been developed according to the estimates of EBRD specialists); the complexity in 
the rules of foreign trade and its structure (as assessed by Doing Business experts); existing shortcomings in the development of the industrial sector, etc. This characterizes the weakness of the institutional basis of the EAEU, which does not allow development and effectively carrying out reforms in the financial sector, etc.

Summing up, we can also conclude that it is difficult to make forecasts and assess the prospects of integration processes based on a qualitative comparison of indicators or other methods in the conditions of a short-term effect in the case of the EAEU region. Integration effects should be checked for longer periods than the activities of the EAEU countries and, possibly, a qualitative assessment should be supported by quantitative methods, for example, predictive dynamics of the main macroeconomic indicators of countries or other methods of economic and mathematical modeling for a more accurate and reliable analysis.

\section{AUTHORS' CONTRIBUTIONS}

The authors made an equal contribution to the study: collection and analysis of material; definition of goals and objectives, research methods; formulation and scientific substantiation of conclusions, registration of key research results in the form of an article.

\section{REFERENCES}

[1] A.A. Dynkin, E.A. Telegina, G.O. Khalova, "The role of the Eurasian Economic Union in the formation of Great Eurasia", World Economy and International Relations, 2018, vol. 62(4), pp. 5-24. (In Russ.). DOI: 10.20542/0131-2227-2018-62-4-5-24

[2] N.A. Navrotskaya, N.Y. Sopilko, S.V. Shamsheev, R.S. Bolotova, N.V. Bondarchuk, E.V. Margolina, "The assessment of the development of foreign trade relations of Russia based on the cointegration analysis", International Journal of Civil Engineering and Technology, 2019, vol. 10(2), pp. 1899-1911.

[3] J. König, "European Integration and the Effects of Country Size on Growth", Journal of Economic Integration, 2015, vol. 30(3), pp. 501531. DOI: 10.11130/jei.2015.30.3.501

[4] M. Emiris, "Measuring capital market integration", BIS Papers chapters, in "Market functioning and central bank policy", 2002, vol. 12, pp. 200-221.

[5] Y. Feng, G. Genna, "Regional integration and domestic institutional homogeneity: A comparative analysis of regional integration in the Americas, Pacific Asia, and Western Europe", Review of International Political Economy, 2003, vol. 10(2), pp. 278-309.

[6] S. Zaidi, Z. Wei, A. Gedikli, M. Zafar, F. Hou, Y. Iftikhar, "The impact of globalization, natural resources abundance, and human capital on financial development: Evidence from thirtyone OECD countries", Resources Policy, 2019, vol. 64, p. 101476 . DOI: 10.1016/j.resourpol.2019.101476

[7] "Central Asia: Increasing Gains from Trade Through Regional Cooperation in Trade Policy, Transport, and Customs Transit”, Asian Development Bank, Manila: ADB, 2006. Retrieved from https://www.adb.org/publications/central-asiaincreasing-gains-trade-through-regionalcooperation-trade-policy-transport

[8] N.Y. Sopilko, E.A. Kovaleva, A.F. Orlova, A.V. Grigoryeva, N. Navrotskaya, "Dynamics factors and slow-response characteristics of Russian trade ties", Journal of Advanced Research in Law and Economics, 2017, vol. 8(2), pp. 625-634. DOI: 10.14505/jarle.v8.2(24).33

[9] "The Gravity Model in International Trade. Advances and Applications", Ed. by P. Bergeijk, S. Brakman, Cambridge: Cambridge University Press, 2010.

[10]N.Yu. Sopilko, I.Yu. Eremina, V.M. Tumin, "On the Implementation of the Goals of Sustainable Development of the Region in the Field of Energy (on the Example of the Member Countries of the Eurasian Economic Union)". BENEFICIUM, 2021, vol. 2(39), pp. 90-96. DOI: 10.34680/BENEFICIUM.2021.2(39).9096

[11]"World economic outlook databases", International Monetary Fund, 2021. Retrieved from

https://www.imf.org/en/Publications/SPROLLs/ world-economic-outlookdatabases\#sort=\%40imfdate\%20descending

[12] "World Population Prospects 2019”, United Nations, Department of Economic and Social 
Affairs, Population Dynamics, 2020. Retrieved from https://population.un.org/wpp/

[13] "EAEU Statistics", EEC, 2021. (In Russ.). Retrieved from http://www.eurasiancommission.org/ru/act/integ r_i_makroec/dep_stat/union_stat/Pages/default.a spx

[14] "Regional Economic Prospects", European Bank for Reconstruction and Development, 2021. Retrieved from http://www.ebrd.com/what-we-do/economicresearch-and-data/data/forecasts-macro-datatransition-indicators.html

[15] “Doing business 2019”. The World Bank, 2018. Retrieved from https://www.doingbusiness.org/content/dam/doi ngBusiness/media/AnnualReports/English/DB19-Report.pdf

[16] "World Economic Forum”, 2020. Retrieved from https://www.weforum.org/

[17] "Gini index (World Bank estimate)", The World Bank, 2019. Retrieved from http://www.data.worldbank.org

[18]I.V. Leskova, G.I. Osadchaya, I.A. Seleznev, "The development features of migration policy within the integration processes structure of
EAEU", in Proceedings of the $45^{\text {th }}$ ISC on Economic and Social Development - XIX International Social Congress, 2019, pp. 820826.

[19] "Human Development Index (HDI) Ranking", United Nations Development Programme. Human Development Report, 2020. Retrieved from http://www.hdr.undp.org

[20] O.V. Butorina, "The specifics of the Eurasian model of economic integration", Contemporary Europe, 2016, vol. 2(68), pp. 28-32. (In. Russ.). DOI: $10.15211 /$ soveurope220162832

[21] A.A. Migranyan, "Structural effects of Eurasian integration", International Trade and Trade Policy, 2019, vol. 3, pp. 103-123. (In Russ.). DOI: 10.21686/2410-7395-2019-3-103-123

[22]R.I. Khazbulatov, "State of the UAEU integration group and prospects for its development", in Proceedings of the National Scientific and Practical Conference "Digital economy: trends and prospects of development" [Tsifrovaya ekonomika: tendentsiya i perspektivy razvitiya], 2020, pp. 113-116. (In Russ.). 